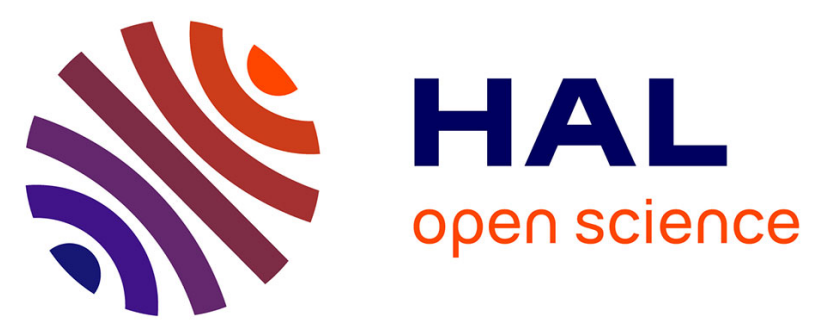

\title{
The Introduction Process of Low-Volume Products: Challenges and Potentials of Information Management
}

\author{
Siavash Javadi, Mads Bejlegaard, Ann-Louise Andersen, Jessica Bruch
}

\section{To cite this version:}

Siavash Javadi, Mads Bejlegaard, Ann-Louise Andersen, Jessica Bruch. The Introduction Process of Low-Volume Products: Challenges and Potentials of Information Management. IFIP International Conference on Advances in Production Management Systems (APMS), Sep 2016, Iguassu Falls, Brazil. pp.325-332, 10.1007/978-3-319-51133-7_39 . hal-01615788

\author{
HAL Id: hal-01615788 \\ https://hal.inria.fr/hal-01615788
}

Submitted on 12 Oct 2017

HAL is a multi-disciplinary open access archive for the deposit and dissemination of scientific research documents, whether they are published or not. The documents may come from teaching and research institutions in France or abroad, or from public or private research centers.
L'archive ouverte pluridisciplinaire HAL, est destinée au dépôt et à la diffusion de documents scientifiques de niveau recherche, publiés ou non, émanant des établissements d'enseignement et de recherche français ou étrangers, des laboratoires publics ou privés. 


\title{
The Introduction Process of Low-Volume Products: Challenges and Potentials of Information Management
}

\author{
Siavash Javadi ${ }^{1 *}$, Mads Bejlegaard ${ }^{2}$, Ann-Louise Andersen ${ }^{2}$, and Jessica Bruch ${ }^{1}$ \\ ${ }^{1}$ Mälardalen University, Eskilstuna, Sweden \\ ${ }^{2}$ Aalborg University, Aalborg, Denmark \\ \{siavash.javadi, jessica.bruch\}@mdh.se
}

\begin{abstract}
The product introduction process plays an important role in development of new products and launching them to the market on-time with a high quality. The product introduction process has been studied primarily in high-volume manufacturing industries and therefore, the influences of the characteristics of low-volume manufacturing industries on the product introduction process has not been investigated. The aim of this paper is to study challenges and potentials of information management during the product introduction process in low-volume manufacturing industries by a multiple-case study in two Scandinavian low-volume manufacturing companies. The paper contributes in covering the knowledge gap about the information management during the product introduction process in low-volume manufacturing industries.
\end{abstract}

Keywords: Design-manufacturing interface $\cdot$ Product development $\cdot$ Productiondesign integration

\section{Introduction}

Manufacturing companies are forced to develop and launch new products to the market more frequently with a high quality because of different factors such as in-creased competition in the globalized market, introduction of new technologies and faster obsolescence of the products. The product introduction process as the final sub-process of the product development is of high importance to reduce the production disturbances during the early stages of the production of new products and to reach the intended quality, production goals and time to market/payback [1,2]. An effective management of information in the product introduction process is central for the success of the product introduction process $[3,4,5,6]$.

Although information management in the product introduction process has been studied in the context of product development [3,7], production system development [5] and production ramp-up [6], the influences of the characteristics of low-volume manufacturing industries on it has remained unexplored. Therefore, the aim of this paper is to study challenges and potentials of information management during the product introduction process in low-volume manufacturing industries. To achieve this aim, a

adfa, p. 1, 2011.

(c) Springer-Verlag Berlin Heidelberg 2011 
multiple-case study has been conducted in two Scandinavian low-volume manufacturing companies.

\section{$2 \quad$ Frame of reference}

The product introduction process is the finishing process of product development projects which is also known as the industrialization process $[8,9]$. The product introduction process influences critical outcomes of the product development projects such as time to market and product quality [4]. Bellgran and Säfsten [8] define the product introduction process as "transferring from engineering design to production including those activities required to make the product manufacturable and to pre-pare production". Fewer disturbances during production, a shorter time to market and higher quality of the products are some outcomes of a well-implemented product introduction process $[6,10]$.

The product introduction process goals are to develop a production system for production of a product $[1,8]$ and to adapt product and production system together to ensure the manufacturability of the product $[1,2]$. Frishammar [3] summarizes the activities of the product introduction process as the mid-phase of new product development process. These activities include development of product and production system, test and refinement of the product functionality mainly by development of engineering prototypes, test and refinement of the production system and adapting the product and production system together by production of pre-series and reaching the production goals and training the production personnel during the production ramp-up [1, 3, 6, 11]. However, the phases of product introduction process in low-volume manufacturing industries are restricted to development of product and production system, testing and refinement of the functionality of the product and limited production of pre-series and no conventional ramp-up phase is feasible $[11,12]$. This is primarily because of high costs, low production volume, and high variety of the products in low-volume manufacturing companies $[11,12]$ which lead to following a full make-to-order production policy [13].

However, the novelty of products and production systems in low-volume manufacturing industries are usually low [11] which can facilitate the product introduction process based on Almgren's [14] model of complexity of product introduction process. The products in low-volume manufacturing industries are usually modified versions of the existing products [11]. In addition, the production systems of low-volume manufacturing companies are usually flexible enough to produce several products and their variants and to accommodate new products to avoid high costs of developing dedicated production systems for each product $[11,12]$.

One of the main sources of disturbances during the product introduction process is lack of integration between design and production [14, 15]. The production-design integration can be achieved by 1 . More formal and structured activities between the departments such as processes, routines and planned meetings and flow of documents 2 . Informal unstructured continuous relationships between departments which lead to developing common understanding, sharing resources and achieving shared objectives [9]. Information management i.e. acquisition, sharing and using the information [5, 7] 
plays an essential role in supporting the design-production integration and avoiding or mitigating disturbances during the product introduction process $[6,7]$ e.g. by reducing uncertainty and equivocality [16]. Therefore, this paper aims at investigating challenges and potentials of information management during the product introduction process in low-volume manufacturing industries, which has not been considered in the literature [15].

\section{Research method}

Case study is a suitable method for in-depth study of a contemporary phenomenon when the knowledge is limited about the phenomenon [17] which was the case for the subject of this study. Two product development projects were selected as cases from two Scandinavian companies based on possession of the characteristics of low-volume manufacturing companies mentioned by Jina et al. [13]. The first case study, hereafter called Case A, was conducted from October 2012 to September 2013 in a company which develops and produces underground construction and mining equipment. The company is a large company with over 1300 employees. The products of the company were produced in five product families including several variants with numerous options to meet the requirements of different customers and markets. The production activities at the company included the final assembly of the products and sub-assembly of some of the product modules.

The second case, here referred to as Case B, was conducted in a company producing earth-moving equipment. The product series contain three main types of machines with a total of 30 variants, which can be further configured through an additional eight parameters with numerous different options to choose from. The vast majority of the products are customized from well-defined modular product architectures. The case study was conducted from august 2014 to June 2015. The company has approximately 150 employees and therefore, is considered as a small-medium enterprise. All of the products offered by the company are developed and produced in the same location, where production activities cover the manual final assembly, and a steel processing setup that includes manual handling of large components and automatic welding.

In both cases, different sources of data were used including the observation of project meetings and events, documents related to the disturbances during the product introduction process and interviews. Eight and three semi-structured interviews were conducted with the product development project team members of Case A and Case B, respectively. In addition, some follow up interviews were conducted with the production operators to validate and complete the findings of the case studies during 2015. The collected data from these interviews were primarily covered. Five and two final assembly operators were interviewed in Company A and Company B, respectively about information on new products received by assembly operators and production equipment for new product introduction. Initially, the gathered data from each case were recorded and analysed separately to understand how information management during the product introduction in low-volume manufacturing industries is influenced 
by the characteristics of such industries. Thereafter, a cross-case comparison was conducted to compare the similarities and differences of the cases.

\section{$4 \quad$ Empirical findings}

\subsection{Case A}

The goal of the product development project was a general modification of one of the existing products. The product was planned to be produced in the existing production system. The assembly line was designed to produce different products with slight changes. Such flexibility was achieved mainly by manual operations, general-purpose tools and material handling equipment.

The product development project was managed according to a stage-gate model and the project team consisted of different functions such as product design, production, product introduction, purchasing, marketing and product support. The product introduction manager responsibility was basically facilitating the product introduction process by coordinating activities between design and production and considering the limitations and requirements of the production system for the production of the new product. This coordination was necessary because of inter-departmental barriers between design and production as well as their separate locations. Some of the main activities followed by the product introduction manager were collecting the requirements of the production and sharing them with the project team during the development phase, coordinating design reviews to update production personnel about new features of the products and the manufacturability implications of those features and developing assembly sequences and instructions during development of the prototypes.

After the product design phase, two prototypes were developed outside of the normal production facilities with very limited contribution of production personnel because of limited human resources and prioritizing involvement of production personnel in the ongoing production over the product development projects. The assembly sequences and instructions were developed during this phase. In addition to the proto-types, four first products were planned as pre-series to be produced in the production system. However, because of low and discontinuous demand for the product, only two of those preseries were produced immediately after the prototypes. Production of the pre-series encountered many disturbances. These disturbances, their causes and solutions were registered in a database. The most frequent and considerable types of these disturbances were lack of information about the product details, lack of considering manufacturability of the products and late consideration of required changes and limitations of the production system. In addition, based on the follow-up interviews, the information received by production about the new products was incomplete, incorrect and/or ambiguous in many cases. 


\subsection{Case B}

The product development project in Case B aimed at developing a completely new generation of a product. The product was planned to be produced in the existing production system with some necessary changes. The production system possessed the same characteristics as in Case A regarding its flexibility to produce different products and their variants.

Because of the small size of the company, the product development project was managed in a less formalized way and with more face-to-face communications which were facilitated by co-location of different functions. The product design phase was conducted with limited involvement from other functions than product development. However, the designers' knowledge about the production system was extensive because of their long experience at the company and continuous informal communication with the production. After the development phase, two prototypes were developed to test and refine the functionality of the product. No pre-series were produced. Instead, mutual adjustments by informal face-to-face communication between design and production and other functions continued after the start of the production to remove the remaining problems and adjust product and production system together.

Among the predominant disturbances during production start-up were difficulties in implementing and specifying an externally-supplied main component. In addition, necessary changes in the production system were implemented late because of limited resources for designing and implementing new tooling, and due to prioritising quick market introduction over an optimal production setup. The follow-up interviews justified that the information about parts were often in-complete or incorrect during production start-up. The respondents also mentioned that a direct communication with few intermediaries between design and production was a great advantage in handling the product introduction. The advantage of this was that the experience of the operators were used directly in development, which in addition increased the awareness of the operators and their perceived project responsibility.

\section{Discussion}

Managing information during the product introduction process was influenced by the characteristics of the studied low-volume manufacturing companies in different ways. Limited resources in both cases led to challenges regarding the production-design integration. In both cases, the early involvement of production in the product introduction process was limited because the production personnel had to prioritise the ongoing production activities over the product development projects. However, some processes such as collecting the requirements of production at the start of development phase, using the design reviews to inform production about the new features of the product and production of four pre-series product were foreseen in Case A. In Case B the integration was supported more by co-location of design and production and informal relations whereas these informal communications were limited in Case A because of interdepartmental barriers and separate locations of design and production. 
The limited integration between design and production resulted also in difficulty of acquiring information from production personnel about the required changes in the production systems and the requirements and limitation of the production system. Furthermore, sharing the information about the new features of the product and their implications for production with the production personnel was challenging because of lack of integration which is in line with the propositions of Frishammar and Ylinenpää [3]. High number of problems caused by neglecting design for assembly guidelines and requirements and limitations of the production systems in Case A and late delivery and installation of the new production equipment in both cases indicate that the information about the requirements and limitations of the production system are not managed properly during the product introduction project in the low-volume manufacturing industries $[6,15]$. This problem was intensified by extra focus of the designers as well as other project team members on the functionality of the products and under-prioritizing the manufacturability of the products because of the high customizability level and variety of the products. Especially in Case A, since the product was a modified version of an existing product, in many instances the effects of the modifications on the other parts and components were not considered and the information about them was not acquired and shared with production.

In addition, because of lack of integration, no formal process was planned for sharing and using the acquired information about the problems and disturbances. In Case A, a database was used for registering the information about product-related problems and their solutions. However, there was no foreseen mechanism for sharing the information with designers and using it in future products. In Case B, the information about problems and disturbances was not documented nor shared. Furthermore, the follow-up interviews showed that the lack of integration affects the characteristics of the information received by production about the new products. In both cases the information was not comprehensive, correct or/and clear in several instances. Incorrect/incomplete information about small connecting parts and incorrect/incomplete assembly instructions are some examples of such problems. There-fore, in many instances using the received information was impossible or difficult.

Beside the lack of integration, limited opportunities for test and refinement of the products and production system caused challenges for acquiring and sharing the information about the disturbances and critical events. Since there were limited opportunities for test and refinement, many of the problems and critical events surfaced late in the project, i.e. after the start of production. Therefore, acquisition of the in-formation about them and eliminating them was not possible during the earlier phases. This lack of information about the disturbances and non-conformities increased the level of information uncertainty [16]. Another factor which affected the information management in the studied product introduction processes was introducing new products in the current production systems with slight modifications. Since the production system was considered primarily "as is" by the product development team, information on the required changes related to the production system development were acquired and shared late. Late consideration of the required changes in production system in Case A and late implementation of them in both cases was partially caused by this characteristic. However, this reduced novelty of production systems in product introduction process in low- 
volume manufacturing companies can potentially lead to reduced complexity of information management. The low newness level of the production system can provide the de-signers and production personnel with information about the introduction of previous products in that production system and help them to avoid similar disturbances during the introduction of new products. The complexity could be reduced even more when the product is a modified version of an existing product like Case A. However, a process should be established to acquire information from the introduction of new products, to share the information with the product development team members including the designers and production personnel and to use it during the introduction of the future products. Table 1 summarizes the discussed challenges and potentials of information management during the product introduction process in low-volume manufacturing companies.

Table 1. The challenges and potentials of information management caused by the characteristics of product introduction process in low-volume manufacturing industries

\begin{tabular}{|c|c|c|}
\hline \multirow{2}{*}{$\begin{array}{c}\text { Characteristics of the } \\
\text { product introduction pro- } \\
\text { cess in low-volume compa- } \\
\text { nies }\end{array}$} & \multicolumn{2}{|c|}{ Information management } \\
\hline & Challenges & Potentials \\
\hline Lack of resources & $\begin{array}{l}\text { - Reduced integration be- } \\
\text { tween design and production } \\
\text {-Difficulty of acquiring nec- } \\
\text { essary information from produc- } \\
\text { tion } \\
\text { - Difficulty of sharing infor- } \\
\text { mation about the new products } \\
\text { with production }\end{array}$ & $\begin{array}{l}\text { - Facilitating acquiring } \\
\text { and sharing the infor- } \\
\text { mation by encouraging } \\
\text { face-to-face and informal } \\
\text { relations by co-location of } \\
\text { design and production }\end{array}$ \\
\hline $\begin{array}{l}\text { Lack of opportunities for } \\
\text { test and refinement of prod- } \\
\text { ucts and production systems }\end{array}$ & $\begin{array}{l}\text { - Fewer opportunities for ac- } \\
\text { quiring information about prob- } \\
\text { lems and disturbances } \\
\text { - Increased information un- } \\
\text { certainties about the products }\end{array}$ & - \\
\hline $\begin{array}{l}\text { Using the similar produc- } \\
\text { tion system for production of } \\
\text { new products }\end{array}$ & $\begin{array}{l}\text { - Late acquisition and sharing } \\
\text { of information about required } \\
\text { changes in production }\end{array}$ & $\begin{array}{l}\text { - Sharing and using in- } \\
\text { formation from introduc- } \\
\text { tion of previous products } \\
\text { to reduce the complexity }\end{array}$ \\
\hline $\begin{array}{l}\text { Modifying existing prod- } \\
\text { ucts instead of developing } \\
\text { completely new products }\end{array}$ & $\begin{array}{l}\text { - Uncertainties about the af- } \\
\text { fected parts and components and } \\
\text { the required information }\end{array}$ & $\begin{array}{l}\text { - Sharing and using in- } \\
\text { formation from introduc- } \\
\text { tion of previous products } \\
\text { to reduce the complexity }\end{array}$ \\
\hline
\end{tabular}




\section{Conclusions}

Regarding its aim, this paper achieved to identify a number of challenges and potentials of information management during the product introduction process in low-volume manufacturing industries. The characteristics of product introduction in low-volume manufacturing industries impose difficulties of timely and complete acquisition and sharing of information between production and design. However, those characteristics provide a potential to facilitate the product introduction process by reusing the information from introduction of previous similar products. In this regard, the paper contributes to covering the knowledge gap about the information management during the product introduction process in low-volume manufacturing industries. The paper also provides practitioners with insights about management of information during the product introduction process.

The paper provides the basis for future research about the further details of information management during the product introduction process in low-volume manufacturing companies and how to use the information management to facilitate and support the product introduction process in such industries.

\section{References}

1. Johansen, K.: Collaborative Product Introduction within Extended Enterprises, in Department of Management and Engineering, Assembly technology, Linköping University, Sweden (2005)

2. Ruffles, P.C.: Improving the New Product Introduction Process in Manufacturing Companies. International Journal of Manufacturing Technology and Management, 1(1): 1-19 (2000)

3. Frishammar, J., Ylinenpää, H.: Managing Information in New Product Development: A Conceptual Review, Research Propositions and Tentative Model. International Journal of Innovation Management, 11(04): 441-467 (2007)

4. Adler, P.S.: Interdepartmental Interdependence and Coordination: The Case of the Design/Manufacturing Interface. Organization Science, 6(2): 147-167 (1995)

5. Bruch, J., Bellgran, M.: Characteristics Affecting Management of Design Information in the Production System Design Process. International Journal of Production Research, 51(11): 3241-3251 (2013)

6. Fjällström, S., et al.: Information Enabling Production Ramp-Up. Journal of Manufacturing Technology Management, 20(2): 178-196 (2009)

7. Frishammar, J.: Managing Information in New Product Development: A Literature Review. International Journal of Innovation and Technology Management, 2(03): 259-275 (2005)

8. Bellgran, M., Säfsten, K.: Production Development: Design and Operation of Production Systems: Springer London (2010)

9. Berglund, M., U. Harlin, Gullander, P.: Challenges in a Product Introduction in a CrossCultural Work System - A Case Study Involving a Swedish and a Chinese Company. In: The 5th international Swedish production symposium: Linköping, Sweden (2012)

10. Almgren, H.: Towards a Framework for Analyzing Efficiency During Start-Up: An Empirical Investigation of a Swedish Auto Manufacturer. International Journal of Production Economics, 60: 79-86 (1999) 
11. Javadi, S., J. Bruch, Bellgran, M.: Characteristics of Product Introduction Process in LowVolume Manufacturing Industries: A Case Study. Journal of Manufacturing Technology Management, 27(4) (2016)

12. Andersen, A.-L., et al.: Investigating the Impact of Product Volume and Variety on Production Ramp-up. In: The 8th World Conference on Mass Customization, Personalization, and Co-Creation: Montreal, Canada (2015)

13. Jina, J., A.K. Bhattacharya, A.D. Walton.: Applying Lean Principles for High Product Variety and Low Volumes: Some Issues and Propositions. Logistics Information Management, 10(1): 5-13 (1997)

14. Almgren, H.: Pilot Production and Manufacturing Start-up in the Automotive Industry. Principles for Improved Performance, Chalmers University of Technology: Gothenburg (1999)

15. Surbier, L., G. Alpan, Blanco, E.: A Comparative Study on Production Ramp-up: State-ofthe-Art and New Challenges. Production Planning \& Control, 25(15): 1264-1286 (2014)

16. Frishammar, J., H. Florén, Wincent, J.: Beyond Managing Uncertainty: Insights from Studying Equivocality in the Fuzzy Front End of Product and Process Innovation Projects. Engineering Management, IEEE Transactions on, 58(3): 551-563 (2011)

17. Meredith, J.: Building Operations Management Theory Through Case and Field Research. Journal of Operations Management, 16(4): 441-454 (1998) 